Kansas State University Libraries

New Prairie Press

\title{
Immigration, Racial Profiling, and White Privilege: Community- Based Challenges and Practices for Adult Educators
}

Luis Kong

San Francisco State University

Follow this and additional works at: https://newprairiepress.org/aerc

Part of the Adult and Continuing Education Administration Commons

(c) (i) (9)

This work is licensed under a Creative Commons Attribution-Noncommercial 4.0 License

\section{Recommended Citation}

Kong, Luis (2010). "Immigration, Racial Profiling, and White Privilege: Community-Based Challenges and Practices for Adult Educators," Adult Education Research Conference. https://newprairiepress.org/aerc/ 2010/papers/43

This is brought to you for free and open access by the Conferences at New Prairie Press. It has been accepted for inclusion in Adult Education Research Conference by an authorized administrator of New Prairie Press. For more information, please contact cads@k-state.edu. 


\title{
Immigration, Racial Profiling, and White Privilege: Community-Based Challenges and Practices for Adult Educators
}

\author{
Luis Kong, San Francisco State University, USA
}

\begin{abstract}
This study explores the significance of race from a social constructionist perspective. Examples of legal cases set the stage for current definitions of whiteness and racial identification. A community-based transformational organizing model is explained by describing the challenges and educational strategies used by an immigrant rights organization. The conclusion will reflect on how and in what ways this transformative, organizing approach involves relational and contextual dialogue to build a community of learners through action.
\end{abstract}

\section{Introduction}

AMERICAN SOCIETY IS CONTROLLED AND STRUCTURED, NOT JUST BY THE INTERACTION OF ITS CITIZENS, BUT BY ITS LAWS AND BY THE INTERACTION BETWEEN THE ACTIONS OF INSTITUTIONS THAT INTERPRET THOSE LAWS. Since September 11 and the passage of the Patriot Act of 2001, the climate for racial profiling has intensified as Federal agencies expand their effort to apprehend undocumented immigrants with criminal records, in many cases with the assistance of local law enforcement. Immigrants, at different times during the history of this country, have had to negotiate the prevailing social and legal racial definitions that perpetuate exclusion of those who are not "American" and include those who are. Is not being American, not being white? White identity, in many parts of the world, comes with significant privileges, and immigrants have evade popular sentiment by becoming white, as well as by honoring their voices and countering the profiling of their racial identity.

\section{Theoretical Perspective}

Race: A Social Constructionist View - Omi and Winant's (1994) racial formation process asserts that race is a socially constructed concept. This process provides an explanation of the formation of racial identity over time as a social construct influenced by social forces or projects that, depending on who wins in the ideological struggle, establishes both collectively and individually concepts of race. The accumulation of these projects establishes, perpetuates, or challenges the racial identity. The definition of race is grounded in inequality and on power relationships. Racism relies on perceived differences for one group to gain social, economic, or class power over another, even though, biologically, there are more similarities among people than differences. Racial profiling is the externalizing of those power relationships.

From a social constructionist framework, immigrants are the recipients of a socially constructed set of codes serving a racialized system of privilege. By resisting and in turn socially constructing their own set of codes and language through dialogue and action, and through the creation of their own social, cultural institutions, immigrants can promote a sustainable selfidentity, manage a more complex view of race and racial relations, and participate as active 
citizens in social change. Their challenge is to be able to generate new meanings that can mobilize and support their beliefs and hopes for a better life for themselves and their families.

Racial identity is the friction between how I choose to identify myself and how others, including the larger historical and legal narratives, describe me, construct a picture of who I am. To what degree one defines me as Chinese, Latino, American depends on the circumstance, language, institutions, and location where those interactions take place. Racial identity can be situational and changeable. The changes of location result in inclusion and exclusion in as far as how people have viewed racial identity over time and how this perception has influenced the beliefs and therefore the responses to privilege and oppression among people of different racial identities (Kong, 2008). Racism has been woven into everyday life. It has becomes so seamless that it is an acceptable common experience among people of color, and the self-interest of white elites are served by white privilege (Delgado and Stefancic, 2007).

Our personal narrative becomes a part of a common dialogue that resists, by its multiple realities, a system of oppression and conflict. The task for adult educators is to build institutions and social movements able to construct vital narratives that perpetuate a society built on relationships, rather than a market system build on consumerism.

The importance of seeing immigration and immigrant rights from a social constructionist framework has relevant implications for adult education and adult educators. A social construction perspective offers an opportunity to build a new set of language codes and transform the future. The opportunity of validating the self-definition of a people without "essentializing" their inner qualities as a unique characteristic of a group allows for a reconstruction of political and social classifications (Gergen, 1999). Immigrants can begin to interpret the world in which they live with a new awareness of their conditions and challenges. This generative dialogue can guide immigrants to resist racial profiling and act in a way that is authentic to their culture and social needs by valuing what works in their community and building a dialogic space where they can learn together, be honored and heard. The racial formation model is a way to analyze and assess the community action required by organizations advocating for active, participatory citizenship by immigrants. Building generative dialogues and a relational culture develops social projects that counter the prevailing social ideology. This relational practice values community stories that in turn generate new social capital.

The development of racial identity among immigrants has had an impact in their increasingly active participation in American society. Historically, immigration law has perpetuated the construction and definition of whiteness since the colonization of America to now. Legal precedents between plaintiffs and the government have provided the ground for racial and social projects to challenge who is or is not white and therefore who is or is not a citizen historically. As early as 1790 , the U.S. courts established naturalization laws in order to include or exclude immigrants, and by siding with popular racial sentiment through legal means, it created the power to define Caucasian or whiteness as the preferred immigration status (Jacobson, 1998). In 1878, the case of In re Ah Yup, a naturalized American citizen, the Circuit Court under Judge Sawyer for the first time defined the term Caucasian as meaning white and extending from most of Europe to western Asia (Jacobson, 1998). The Rodriguez case a few years later would raise further questions that included the skin color of immigrants seeking naturalization.

Banks (2006) describes an 1896 Texas federal district court case of Ricardo Rodriguez, a Mexican national applying to become a U.S. citizen. He was of Mestizo ancestry, the mixture of white and Indian. The decision before the court was to decide whether Rodriguez was Indian, 
black, or white. According to Banks, Rodriguez did not identify himself as Indian, but as "PureBlooded Mexican" (p. 28). Banks writes, "Rodriguez's refusal to be classified as white, black or Indian reflects the ambivalence of Mexicans generally to define themselves in racial terms" (2006, p. 30). This case shows a historical precedent deeply entrenched in an ideology that argues for whiteness as a superior condition for immigration. Non-Europeans were excluded as non-citizens, whereas an increasing number of Europeans and others who were racially ambiguous laid claim to becoming white citizens. New immigrants, particularly, European immigrants, were on their way to becoming white.

Mae Nagai explains that The Immigrant Act of 1924 was the most significant piece of legislation that "contributed to the racialization of immigrant groups around the notions of whiteness, permanent foreignness and illegality — categories of difference that have outlived the racial categories created by eugenics and post-world I nativism"(in Roediger, 2005, p. 155). In the early 1900s, politicians responded to Mexican immigration increases by criminalizing illegal entry and expanding border patrol enforcement that targeted Mexicans and Mexican Americans beyond the border area (Roediger, 2005). As other European immigrants moved closer to whiteness, Mexican immigrants were moving further away from it. The current criminalization of Mexican undocumented immigrants mirrors the response to unauthorized entry in 1929.

\section{Methodology}

This action research began in 2006 when H.R. 4437, also known as the Sensenbrenner Bill, was passed in the House of Representatives. As a researcher-participant, my questions are how and in what way is a transformative model of adult education implemented to educate immigrants about their constitutional rights? What actions are necessary to counter the racial profiling of law enforcement against immigrant families? How and in what way are public dialogic spaces created in the community and what kind of actions results from these conversations? Through conversations and mutual learning with community organizers, family members, action participants, I began to explore, reflect and learn by participating in a number of large-scale social and legal action focusing on immigrant rights issues.

\section{Implications for Adult Theory and Practice}

A transformative model of community adult education can be implemented through organizing teach-ins, marches, constitutional rights workshops, constitutional rights cards distributions, house meetings, lawsuits, immigrant leadership development, as well as partnership with labor, social, civic and human rights organizations. By taking an active role in making history, people begin to learn about themselves, critically reflect on their identity and learn to engage in organizing for social change. According to DeRienzo (2008) there are three types of organizing efforts: organizing for domestication, organizing around issues -issuespecific mobilization-and transformative/developmental organizing. He explains that the educational objectives of a transformative/developmental type of organizing lies in the community's ability to create a democratic process for the long haul that seeks to change power structures and community isolation by developing public spaces for dialogue, local control, and institutional accountability and political involvement (2008).

The role of the adult educator-organizer is to facilitate a deeper dialogue and questioning about the relationship between white privilege and racism, immigration and the law, and the challenges of leadership and citizenship. The development of a political consciousness can spark 
a person's understanding of the importance of his or her vote. But more so, this reflective consciousness is a key element to understanding the importance the individual has in organizing a significant and powerful collective that can make local elected official accountable for the well-being of the individuals' families and communities.

\section{Education for Social Change: The Committee for Immigrant Rights}

In 2006, a teach-in on H.R. 4437 was held at a local Catholic church and was attended by more than 500 immigrants, supporters, and religious staff, including United Farm Workers (UFW). As a co-founder of CIRSC, I researched information about H.R 4437 and trained teams of facilitators to lead a workshop introducing this immigration bill to participants. This group of educators and activists later became the Committee for Immigrant Rights of Sonoma County (CIRSC), an affiliation of immigrant rights and civic, labor, legal and religious organizations.

The organizing effort of the CIRSC has included vigils, marches, petition campaigns, community legal forums and building a base of volunteers and educators to inform and advocate for immigrant rights in Sonoma County, California. In 2006, as a coalition of labor, immigrant, and peace and justice groups, the CIRSC led more than 10,000 individuals and families, primarily Latinos, in the largest march in the history of Sonoma County. A partnership with the Sonoma County Japanese American Citizen's League (SCJACL) printed and distributed more than 30,000 Constitutional Amendment Rights Cards focusing on Fifth and Sixth Amendment rights. The SCJACL saw parallels in the treatment of immigrant to the racial profiling of American citizens of Japanese decent during World War II.

Facilitators were trained to lead house meetings to engage neighbors in conversations about their neighborhood and to discuss the challenges they faced as immigrants. CIRSC organized around issues of law-enforcement abuses primarily against the Mexican community. This organizing effort started with individual meetings with household members who discussed issues such as immigration raids, car impounds, and racial profiling by law enforcement. Individuals agreed to organize a house meeting with family and neighbors to engage in dialogue about problems they were facing with law enforcement, particularly the Sheriff's department. Participants gave voice to their concerns and committed to educating other members of their community. Participants restored a sense of public space in which they got know neighbors, through conversations engaged in an analysis of the things that affect them, and formed social bonds and mutual support. The dialogic process countered the climate of "fear, distrust, loathing, individual insecurity and suspicion" (DeRienzo, 2008, p. 184) of immigration raids and local law-enforcement collaboration.

Institutional accountability and political involvement are two other examples of transformative organizing (DeRienzo, 2008). Institutional accountability came about when the American Civil Liberties Union (ACLU) of Northern California on behalf of CIRSC filed a lawsuit in U.S. District Court in San Francisco against the County of Sonoma and U.S. Department of Homeland Security, Bureau of Immigration and Custom Enforcement and the Sonoma County Sheriff's Department for allegations of racial profiling and for aggressively stopping and searching people who are in the majority Latino. The suit claims that the members of the Sheriff's Department have been illegally interrogating them about their immigration status based on their race, and detaining immigrants in county jail without due process. In an effort to establish a County of Refuge in Sonoma County, California, the Committee for Immigrant Rights of Sonoma County (CIRSC) is engaging its members in political involvement. The County of Refuge Campaign works in conjunction with other immigrant-rights efforts to contact 
county supervisors and local city councils to establish a County of Refuge ordinance barring immigration raids and collaboration with ICE by law enforcement in non-criminal cases.

\section{Challenges of Adult Educators Engaged in Social Change}

As adult educators, we can improve our practice by developing a positive learning environment where students and community participants can contribute their stories of struggle while deconstructing and transforming learning through dialogue and participation that decentralizes teaching and distributes it among the learners. The development of house meetings as a relational organizing process has encouraged neighbors to engage in conversation about their constitutional rights while constructing a sense of community and leadership among the participants. The challenge is for adult educators to sustain their organizing efforts through consistent training of community leaders, seek funding and time to accomplish tasks, and build coalitions with individuals and organizations who are ideological allies, but with different institutional cultures. A constant effort to engage in conversation has created long-term partnerships and trust.

The transformational process is evident in the communal relations between people who, through reflection and action, become actors in their own defense. These relational meetings between organizations and the community lend themselves to community groups directing their knowledge to what is most important to them rather than being fed the education they need to fight injustice. The community-based adult educator facilitates these exchanges and the desire of participants to take charge of their own problems by taking leadership with others.

The efforts of the Committee for Immigrant Rights is a successful model of communitybased adult education projects that provides a generative and dialogic public space, institutional accountability, and political action in the struggle against racial profiling and racism and in favor of a reflective and informed immigrant community.

\section{References}

Banks, T. L. (2007). "Mestizaje and the Mexican Mestizo Self: No Hay Sangre Negra, So There Is No Blackness." http://ssrn.com/abstract=790625. July 28, 2007.

Delgado, R., and Stefancic, J. (2007). "Critical Race Theory: An Introduction." New York: NYU Press.

DeRienzo, H. (2008). "Community Organizing for Power and Democracy: Lessons Learned from Life in the Trenches." In J. DeFilippis and S. Saegert (eds.), The Community Development Reader. New York: Routledge.

Gergen, K. J. (1999). “An Invitation to Social Construction.” Thousand Oaks, Calif.: Sage.

Jacobson, M. F. (1998). "Whiteness of a Different Color: European Immigrants and the Alchemy of Race." Cambridge, Mass: Harvard University Press.

Kong, L. (2008 ). "I Am More from Here Than from There: The Role of Citizenship Schools in The Construction of Racial Identity Among Older Adult Immigrants." Paper presented at the Adult Education Research Conference, St. Louis, Mo.

Omi, M., and Winant, H. (1994). "Racial Formation in the United States: From the 1960s to the 1980s" (2nd ed.). New York: Routledge.

Roediger, D. (2005). "Working Toward Whiteness: How America's Immigrants Became White." New York: Basic Books, 2005. 